\title{
UPAYA MENINGKATKAN HASIL BELAJAR MELALUI PENERAPAN MODEL PEMBELAJARAN KOOPERATIF TIPE TGT (TEAMS GAMES TOURNAMENT) DI SMP NEGERI 1 SAKRA BARAT
}

\author{
B. Minardiningsih \\ SMP Negeri 1 Sakra Barat \\ minardiningsih68@gmail.com
}

\begin{abstract}
This study aims to determine whether through the application of the TGT cooperative learning model can improve the learning outcomes of the Human Reproductive System, and also to determine the response of students to the application of cooperative learning learning models. The type of research conducted is PTK with a qualitative approach. Research data in the form of learning outcomes obtained in the study as much as 2 cycles. Data on student learning outcomes are collected from the pre-test and post-test scores given by researchers in each cycle. The results of the study showed that the application of the TGT cooperative learning model could improve the learning outcomes of students in class IX.A SMPN 1 Sakra. This can be seen in the percentage increase in learning outcomes in cycle II is greater than cycle I. The average post-test score of cycle I is 64, while the average post-test score of cycle II is 70 . Percentage of increase in mastery learning in cycle I students amounting to $56 \%$ while the percentage increase in learning completeness of students in cycle II was $85 \%$.
\end{abstract}

Keywords: Learning, Cooperative Method, Type TGT

\begin{abstract}
Abstrak : Penelitian ini bertujuan untuk mengetahui apakah melalui penerapan model pembelajaran kooperatif tipe TGT dapat meningkatkan hasil belajar Sistem Reproduksi Manusia, dan juga untuk mengetahui respon peserta didik terhadap penerapan model pembelajaran kooperatif learning. Jenis penelitian yang dilakukan adalah PTK dengan pendekatan kualitatif. Data penelitian berupa hasil belajar diperoleh dalam penelitian sebanyak 2 siklus. Data hasil belajar peserta didik dikumpulkan dari skor pre-tes dan post-tes yang diberikan peneliti pada setiap siklus. Hasil penelitian menunjukkan bahwa penerapan model pembelajaran kooperatif tipe TGT dapat meningkatkan hasil belajar peserta didik kelas IX.A SMPN 1 Sakra Barat. Hal ini terlihat pada persentase peningkatan hasil belajar pada siklus II lebih besar dari siklus I. rata - rata skor post-test siklus I sebesar 64, sedangkan rata-rata skor post-test siklus II sebesar 70. Persentase peningkatan ketuntasan belajar peserta didik siklus I sebesar $56 \%$ sedangkan persentase peningkatan ketuntasan belajar peserta didik siklus II sebesar $85 \%$.
\end{abstract}

Kata Kunci : Pembelajaran, Metode Koperatif, Tipe TGT 


\section{PENDAHULUAN}

Pendidikan menengah pertama merupakan pendidikan yang berusaha untuk menyiapkan peserta didik menjadi calon peserta didik yang kompeten yang akan melanjutkan ke jenjang yang lebih tinggi baik ke pendidikan menengah atas (SMA) atau pendidikan menengah kejuruan (SMK) kesehatan. Untuk mencapai kompetensi yang sesuai dengan minat dan bakatnya di kemudian hari maka materi pelajaran dikemas dalam berbagai mata pelajaran yang dikelompokkan menjadi dua kelompok mata pelajaran yaitu kelompok normatif dan adaptif.

Proses pendidikan merupakan proses yang dilakukan secara sistematis dalam rangka pembinaan dan pengembangan aspek-aspek perilaku yang dimiliki oleh peserta didik. Melalui pendidikan peserta didik akan memperoleh pengalamanpengalaman baru yang berkaitan dengan pola-pola tingkah laku dari peserta didik tersebut. Demikian juga halnya dengan sekolah menengah pertama sebagai lembaga formal yang berusaha untuk menyiapkan lulusannya sebagai calon peserta didik yang siap melanjutkan ke jenjang yang lebih tinggi.

SMP Negeri 1 Sakra Barat merupakan salah satu lembaga formal yang didirikan oleh pemerintah bertujuan untuk menghasilkan calon peserta didik baru yang akan melanjutkan ke SMA maupun SMK dan secara umum siap menghadapi persaingan regional maupun nasional dengan bekal kemampuan yang dimilikinya selama menuntut ilmu. Tuntutan persaingan regional maupun nasional yang dihadapi oleh SMP Negeri 1 Sakra Barat hakikatnya adalah merupakan tuntutan yang dihadapi juga oleh peserta didik SMP Negeri 1 Sakra Barat untuk lebih giat mempelajari mata pelajarannya. Salah satu materi yang diajarkan pada mata pelajaran IPA Terpadu adalah Sistem Reproduksi Manusia Mata pelajaran ini diberikan pada peserta didik kelas IX.A.

Sebagai mata pelajaran adaptif, berdasarkan penetapan Kriteria Ketuntasan Minimal (KKM) untuk mata pelajaran IPA Terpadu, peserta didik dinyatakan lulus harus memperoleh nilai $\geq 7,00$. Akan tetapi dari hasil ulangan harian yang dilakukan terhadap 33 peserta didik, yang memperoleh nilai $\geq 7,00$ hanya 9 orang peserta didik. Dengan demikian ketuntasan belajar peserta didik pada mata pelajaran ini cukup rendah karena sebagian besar peserta didik belum memperoleh nilai sesuai dengan standar yang telah ditetapkan. 


\section{KAJIAN TEORI}

\section{Pengertian Belajar}

Istilah belajar sudah dikenal luas di berbagai kalangan walaupun sering disalahartikan. Untuk memahami konsep belajar secara utuh, maka perlu digali pendapat berbagai ahli mengenai belajar. Pendapat para ahli ini sangat penting untuk memahami konsep belajar. Berikut ini pendapat beberapa ahli mengenai konsep belajar.

Bell-Gredler menyatakan belajar merupakan proses yang dilakukan oleh manusia untuk mendapatkan aneka ragam competencies, skill, and attitudes. Kemampuan (competencies), keterampilan (skills), dan sikap (attitudes) tersebut diperoleh secara bertahap dan berkelanjutan mulai dari masa bayi sampai masa tua melalui rangkaian proses belajar sepanjang hayat. ${ }^{1}$

Menurut Winkel, belajar berarti perubahan tingkah laku atau penampilan dengan serangkaian kegiatan, misalnya membaca, mengamati, mendengarkan, dan meniru. Belajar akan lebih efektif apabila si pembelajar melakukannya dalam suasana yang menyenangkan dan dapat menghayati obyek pembelajaran secara langsung ${ }^{2}$

Hilgard mengatakan: "Learning is the prosess by which an activity originates or is changed through training procedures". Belajar adalah proses yang melahirkan atau mengubah suatu kegiatan melalui jalan latihan ${ }^{3}$

Selanjutnya Simanjuntak menyatakan belajar sebagai suatu proses perubahan kegiatan, reaksi terhadap lingkungan. ${ }^{4}$ Perubahan tersebut tidak dapat disebut belajar apabila disebabkan oleh pertumbuhan atau keadaan sementara seseorang seperti kelelahan atau disebabkan obat-obatan.

Dari beberapa uraian mengenai pengertian belajar di atas, maka dapat ditarik kesimpulan bahwa yang dimaksud dengan belajar adalah proses perubahan yang meliputi pengetahuan, kecakapan, tingkah laku dan perubahan tersebut diperoleh

${ }^{1}$ Winatasaputra, Udin S. dkk.2009. Teori Belajar dan Pembelajaran. Jakarta. Universitas Terbuka. 2 Angkoro, R. dan Kosasih, A. 2007.Optimalisasi Media Pembelajaran.Jakarta. PT. Grasindo.

${ }^{3}$ Nasution, S. 2006. Berbagai Pendekatan dalam Proses Belajar \& Mengajar. Jakarta : Bumi Aksara.

${ }^{4}$ IL Pasaribu, B Simandjuntak.1983. Proses Belajar Mengajar. Bandung: Tarsito 
melalui pengalaman bukan perubahan yang dengan sendirinya karena pertumbuhan kematangan.

Dalam proses belajar terdapat 3 (tiga) hal yang menjadi ciri belajar yaitu : (1) belajar memungkinkan terjadinya perubahan prilaku pada individu, (2) perubahan itu merupakan buah dari pengalaman, (3) perubahan tersebut relatif meningkat ${ }^{5}$

\section{Hasil Belajar}

Proses belajar mengajar yang dilakukan di sekolah salah satu upaya dalam kegiatan pembelajaran untuk mencapai hasil belajar. Hasil belajar merupakan tujuan akhir dilaksanakannya kegiatan pembelajaran di sekolah. Hasil belajar dapat ditingkatkan melalui usaha sadar yang dilakukan secara sistematis, mengarah kepada perubahan yang positif yang kemudian disebut dengan proses belajar. Akhir dari proses belajar adalah perolehan suatu hasil belajar peserta didik. Hasil belajar peserta didik di kelas terkumpul dalam himpunan hasil belajar kelas. Semua hasil belajar tersebut merupakan hasil dari suatu interaksi tindak belajar dan tindak mengajar. Dari sisi guru, tindak mengajar diakhiri dengan proses evaluasi hasil belajar, sedangkan dari sisi peserta didik, hasil belajar merupakan berakhirnya penggal dan puncak proses belajar $^{6}$

Hasil belajar peserta didik dipengaruhi oleh dua faktor utama yaitu faktor dari dalam diri peserta didik dan faktor yang datang dari luar diri peserta didik atau faktor lingkungan. Faktor dari dalam diri peserta didik terutama menyangkut kemampuan yang dimiliki peserta didik. Slark, mengungkapkan bahwa hasil belajar peserta didik di sekolah $70 \%$ dipengaruhi oleh kemampuan peserta didik dan $30 \%$ dipengaruhi oleh lingkungan. Berkaitan dengan faktor dari dalam diri peserta didik, selain faktor kemampuan, ada juga faktor lain yaitu motivasi, minat, perhatian, sikap, kebiasaan belajar, ketekunan, kondisi sosial ekonomi, kondisi fisik dan psikis. Salah satu faktor lingkungan yang paling dominan mempengaruhi hasil belajar adalah kualitas pengajaran. Yang dimaksud kualitas pengajaran adalah tinggi rendahnya atau efektif tidaknya proses pembelajaran dalam mencapai tujuan instruksional. Teori belajar di sekolah (Theory of school learning) dari bloom, bahwa ada 3 (tiga) variabel utama dalam

${ }^{5}$ Winatasaputra, Udin S. dkk.2009. Teori Belajar dan Pembelajaran. Jakarta. Universitas Terbuka. ${ }^{6}$ Dimyati dan Mudjiono. 2009. Belajar dan Pembelajaran. Jakarta. PT. Rineka Cipta. 
teori belajar di sekolah, yaitu karakteristik individu, kualitas pengajaran dan hasil belajar peserta $\operatorname{didik}^{7}$

Selain faktor dari dalam diri dan lingkungan, ada faktor lain yang turut menentukan hasil belajar peserta didik yaitu faktor pendekatan belajar (approach to learning). Carol, berpendapat bahwa hasil belajar peserta didik dipengaruhi oleh 5 (lima) faktor yaitu :

1. Faktor bakat belajar;

2. Faktor waktu yang tersedia untuk belajar;

3. Faktor kemampuan individu;

4. Faktor kualitas pengajaran;

5. Faktor lingkungan ${ }^{8}$

Berdasarkan konsepsi di atas, hasil belajar dapat disimpulkan sebagai perubahan prilaku secara positif serta kemampuan yang dimiliki peserta didik dari suatu interaksi tindak belajar dan mengajar yang berupa hasil belajar intelektual, strategi kognitif, sikap dan nilai, inovasi verbal dan hasil belajar motorik. Perubahan tersebut dapat diartikan terjadinya peningkatan dan pengembangan yang lebih dibandingkan dengan sebelumnya.

\section{Hakikat Belajar dan Hasil Perbaikan Sistem Reproduksi Manusia}

Pembelajaran sebagai proses interaksi dan komunikasi dalam proses pembelajaran. Pendidikan akan berfaedah besar apabila dapat menumbuhkembangkan kepribadian manusia. Pembelajaran harus menjawab kebutuhan peserta didik untuk merencanakan tujuan hidup, bagaimana memilih nilai - nilai, bagaimana membangun identitas diri, bagaimana membentuk ketangguhan diri, dan bagaimana mengupayakan relasi dan komunikasi pribadi yang efektif dengan sesama dan lingkungannya. Secara umum ada 3 (tiga) tujuan pembelajaran, yaitu : 1). Untuk mendapatkan pengetahuan; 2) Untuk menanamkan konsep dan pengetahuan; 3) Untuk membentuk sikap atau kepribadian. Tujuan pendidikan nasional

7 Sudjana, Nana. 2010. Penelitian Hasil Proses Belajar Mengajar. Bandung : PT. Remaja Rosdakarya).

8 Angkoro, R. dan Kosasih, A. 2007.Optimalisasi Media Pembelajaran.Jakarta. PT. Grasindo. 
sebagaimana tercantum dalam UU Sistem Pendidikan Nasional pasal 3 mengenai Tujuan Pendidikan Nasional.

Pendidikan menengah pertama memiliki tujuan untuk membekali peserta didik dengan pengetahuan dan sikap yang baik agar siap melanjutkan ke jenjang yang lebih tinggi, dalam hal ini SMA atau SMK kesehatan maupun yang sederajat. Salah satu mata pelajaran yang ada di SMP adalah IPA Terpadu, dengan salah satu materi sistem reproduksi manusia

Hasil belajar yang diharapkan setelah mengikuti pembelajaran kooperatif TGT ini nantinya diharapkan semua peserta didik memiliki pemahaman yang berhubungan dengan sistem reproduksi manusia. Hasil belajar adalah tes yang digunakan untuk menilai hasil - hasil pelajaran yang telah disampaikan oleh guru pada peserta didik dalam jangka waktu tertentu. Itu artinya dalam mengukur dan mengevaluasi keberhasilan proses maupun hasil belajar digunakan suatu tes untuk mengetahui tingkat belajar kemampuan peserta didik.

Untuk mengetahui ketercapaian proses pembelajaran (hasil belajar) maka setiap peserta didik nantinya akan diuji dengan tes tulis. Setiap peserta didik harus menguasai sampai tuntas materi pelajaran ini melalui unjuk kerja yang dilakukan pada akhir diklat.

\section{Model Pembelajaran Kooperatif Tipe TGT}

Pada model pembelajaran TGT, strategi yang digunakan adalah strategi pembelajaran kooperatif yaitu strategi pembelajaran kelompok yang mampu meningkatkan prestasi belajar peserta didik sekaligus dapat meningkatkan kemampuan hubungan sosial, menumbuhkan sikap menerima kekurangan diri dan orang lain, meningkatkan harga diri, dapat merealisasi kebutuhan peserta didik dalam belajar berfikir, memecahkan masalah serta mengintegrasikan pengetahuan dengan keterampilan.

Metode yang dapat digunakan pada Model Pembelajaran TGT ada berbagai macam, beberapa diantaranya yaitu :

1. Metode Ceramah

Menurut Arikunto, metode ceramah adalah sebuah cara melaksanakan pembelajaran yang dilakukan guru secara monolog dan berlangsung satu 
arah, yaitu dari guru ke peserta didik. ${ }^{9}$ Pada model pembelajaran TGT, metode ceramah dapat digunakan untuk menjelaskan di awal pelajaran, menyimpulkan materi pembelajaran, dan mengonfirmasi bila ada jawaban peserta didik yang perlu diperbaiki.

2. Metode Kerja Kelompok

Metode kerja kelompok adalah metode mengajar dengan mengondisikan peserta didik dalam suatu kelompok sebagai satu kesatuan dan diberikan tugas untuk dibahas dalam kelompok tersebut. Pada model pembelajaran TGT, peserta didik dibagi menjadi beberapa kelompok yang beranggotakan $4-6$ orang untuk menyelesaikan permasalahan tertentu.

3. Metode Diskusi

Pada tipe TGT, peserta didik melakukan diskusi dengan anggota kelompok masing - masing untuk memecahkan suatu permasalahan.

4. Metode Demonstrasi

Metode demonstrasi adalah metode penyajian pelajaran dengan memperagakan dan mempertunjukkan kepada peserta didik tentang suatu proses, situasi atau benda tertentu, baik sebenarnya atau hanya sekedar tiruan. Metode ini pada TGT dapat diterapkan pada saat guru menyajikan informasi.

\section{Metode Problem Solving}

Metode problem solving adalah suatu cara mengajar yang menghadapkan peserta didik ke suatu masalah agar dipecahkan atau diselesaikan. ${ }^{10}$ Pada model pembelajaran kooperatif tipe TGT, peserta didik dihadapkan pada suatu masalah yang terdapat pada LKS atau permasalahan yang diberikan oleh guru untuk dipecahkan dalam kelompok masing - masing.

6. Metode Pemberian Tugas

Metode pemberian tugas dapat diartikan sebagai suatu format interaksi belajar mengajar yang ditandai dengan adanya satu atau lebih tugas yang

${ }_{9}$ Djamarah, Syaeful Bahri (2005) Guru dan Anak Didik dalam Interaksi Anak Didik, Rineka. Cipta,

${ }^{10}$ Sriyono. 1992. Teknik Belajar Mengajar CBSA. Jakarta: Rineka Cipta. 
diberikan oleh guru, tugas tersebut dapat diselesaikan secara individu atau berkelompok. ${ }^{11}$ Pada model pembelajaran TGT, guru memberikan tugas kepada kelompok masing - masing untuk menyelesaikan permasalahan yang diberikannya.

Adapun langkah - langkah yang dilakukan untuk melaksanakan metode TGT adalah sebagai berikut :

\section{Class Presentation (Persiapan Kelas)}

Sebelum pengarahan dimulai, guru menjelaskan metode pembelajaran TGT pada peserta didik, selanjutnya guru menjelaskan secara ringkas konsep - konsep pembelajaran.

\section{Teams (Regu)}

Peserta didik dibagi menjadi kelompok - kelompok kecil terdiri dari 4 - 5 orang peserta didik dengan kemampuan akademik berbeda. Guru memberikan tugas - tugas tentang materi pembelajaran untuk tiap kelompok, siswa bekerja sama dan saling membantu di dalam kelompok untuk mengerjakan tugas tersebut.

3. Games

Setelah selesai diskusi, peserta didik mempersiapkan diri untuk bertanding dalam hal permainan akademis.

\section{Individual Improvement Scores}

Nilai individu siswa dikumpulkan menjadi nilai kelompok dan dicari rata ratanya.Nilai itulah menjadi dasar kemajuan kelompok.

\section{Team Recognition}

Nilai rata - rata kelompok yang tertinggi akan diberi pengakuan seperti diumumkan di depan kelas dan diberi pujian. Jadi dalam pembelajaran TGT peserta didik betul - betul bekerja sama untuk menjadikan kelompoknya yang terbaik, karena kegagalan satu orang merupakan kegagalan kelompok dan keberhasilan satu orang merupakan keberhasilan kelompok.

${ }^{11}$ Sriyono. 1992. Teknik Belajar Mengajar CBSA. Jakarta: Rineka Cipta. 


\section{METODELOGI PENELITIAN}

PTK ini dilaksanakan dalam dua siklus, yaitu sebagai berikut :

\section{Siklus I}

Pada siklus I, kegiatan yang dilakukan adalah pembelajaran pada materi pokok yaitu memahami tentang sistem reproduksi manusia yaitu melalui strategi pembelajaran kooperatif tipe TGT yang didahului dengan penjelasan mengenai kompetensi dasar, tujuan pembelajaran yang akan dicapai. Kemudian peserta didik berkelompok untuk melakukan diskusi soal yang berhubungan dengan pemahaman terhadap sistem reproduksi manusia.

Langkah - langkah tindakannya adalah sebagai berikut :

\section{Perencanaan}

Meliputi penyampaian Rencana Pelaksanaan Pembelajaran (RPP), materi pelajaran, kemudian guru membentuk peserta didik ke dalam beberapa group, membantu pekerjaan peserta didik, latihan soal, pembahasan latihan soal, ulangan harian. Bagian ini berisikan perlakuan yang akan diberikan kepada peserta didik sesuai dengan yang tertulis pada rencana tindakan. Di luar itu adalah pembelajaran biasa yang telah kita lakukan sehari - hari, tidak perlu dituliskan di sini harus dibedakan antara pembelajaran biasa dengan PTK yang dituliskan di siklus hanyalah bagian yang diteliti saja.

2. Tindakan (Action)

Pada fase tindakan ini, kegiatan yang dilaksanakan adalah sesuai dengan skenario atau rencana pembelajaran yang telah disusun.

3. Pengamatan (Observasi)

Pada bagian ini dilaksanakan pengamatan terhadap pelaksanaan tindakan dengan menggunakan lembar yang telah dibuat, kegiatan - kegiatan yang diamati adalah meliputi : pengamatan terhadap keterlaksanaan pembelajaran di kelas dengan menggunakan pendekatan model pembelajaran kooperatif tipe TGT yaitu aktivitas peserta didik dan guru dalam kegiatan pembelajaran yang berhubungan dengan materi yang diajarkan melalui fase elaborasi, eksplorasi, dan evaluasi dengan menggunakan lembar pengamatan yang telah disusun. Hasil - hasil pekerjaan peserta didik yang otentik dapat disajikan di sini. 


\section{Refleksi}

Pada bagian ini perlu adanya pembahasan antara siklus - siklus tersebut untuk dapat menentukan kesimpulanatau hasil dari penelitian.Refleksi berisikan penjelasan tentang keberhasilan atau kegagalan yang terjadi setelah selang waktu tertentu.Refleksi diakhiri dengan perencanaan kembali untuk siklus berikutnya.

\section{Siklus II}

Pada siklus II ini kegiatan yang dilakukan adalah pembelajaran pada materi pokokmendeskripsikan sistem reproduksi manusia dengan model pembelajaran kooperatif tipe TGT. Adapun rencana penelitian yang dilakukan pada siklus ini sesuai dengan refleksi yang dilakukan pada siklus I. tahapan - tahapan penelitian siklus II ini meliputi : rencana tindakan, tindakan pembelajaran, pengamatan, refleksi sesuai dengan tahap pada siklus I kemudian dilanjutkan dengan analisis data.

Setelah proses pengumpulan data dilakukan maka proses selanjutnya yaitu proses analisis data. Dari data yang diperoleh baik itu data kuantitatif maupun data kualitatif maka dilakukan analisis secara deskriptif dan dibandingkan dengan data sebelumnya untuk mengetahui pengaruh pelaksanaan model pembelajaran tipe TGT terhadap hasil belajar peserta didik.

Teknik analisis data yang dilakukan adalah teknik analisis data sederhana yaitu dengan membandingkan jumlah peserta didik yang kompeten (memperoleh nilai $\geq$ $7,00)$ dengan jumlah peserta didik.

Kompetensi dianggap tuntas jika jumlah peserta didik yang kompeten mencapai $\geq 80 \%$.

Adapun rumus Ketuntasan Belajar (KB) klasikal adalah sebagai berikut :

$\mathrm{KB}=\left(\right.$ peserta didik kompeten $/ \sum$ peserta didik seluruhnya $) \times 100 \%$. Disamping itu juga dideskripsikan hasil pengamatan dengan menggunakan lembar observasi yang terjadi pada pelaksanaan proses belajar mengajar. 


\section{PEMBAHASAN}

\section{Hasil Belajar Peserta Didik}

Hasil belajar adalah perubahan - perubahan tingkah laku peserta didik yang dikehendaki benar - benar terjadi setelah peserta didik mengalami proses belajar. Hasil belajar sering disebut dengan prestasi belajar. Prestasi belajar atau hasil belajar peserta didik biasanya dinyatakan dalam skor hasil test. Hasil belajar dalam penelitian ini dinyatakan dalam hasil test yang diberikan pada awal siklus belajar, disebut sebagai pre-test yang diberikan sebelum pembelajaran dan post-test yang diberikan setelah pembelajaran berakhir. Skor yang diperoleh peserta didik dalam pre-test dan post-test dapat digunakan sebagai indikator peningkatan hasil belajar peserta didik dalam penelitian ini. Adanya peningkatan skor peserta didik dari pre-test ke post-test dan skor peserta didik dari siklus I ke siklus II dapat menggambarkan peningkatan hasil belajar peserta didik pada ranah kognitif.

Berdasarkan penelitian yang dilakukan diperoleh data bahwa skor rata-rata post-test pada siklus I mencapai 64 dan siklus II mencapai 70. Berdasarkan data tersebut diketahui bahwa terjadi peningkatan skor rata-rata post-test dari siklus I ke siklus II, dengan demikian dapat dikatakan ada peningkatan hasil belajar. Adanya peningkatan hasil belajar tersebut dapat diketahui bahwa pembelajaran dengan model kooperatif tipe TGT dapat meningkatkan hasil belajar peserta didik. Syarat ketuntasan belajar secara klasikal telah ditetapkan sebesar $85 \%$, dengan ketuntasan masing-masing peserta didik sebesar 70. Pada siklus I ketuntasan belajar klasikal mencapai $56 \%$, dengan demikian pada siklus I dapat dikatakan bahwa secara klasikal tidak mencapai ketuntasan belajar. Persentase ketuntasan pada siklus II mencapai 84.84\%, dengan demikian pada siklus II secara klasikal juga sudah mencapai ketuntasan belajar dan terjadi peningkatan persentase ketuntasan belajar secara klasikal. Hal ini membuktikan bahwa dengan adanya perbedaan ketuntasan belajar dari siklus I ke siklus II dapat dijadikan indikator adanya peningkatan hasil belajar peserta didik. Berdasarkan uraian di atas dapat diketahui bahwa penerapan model pembelajaran kooperatif tipe TGT mampu meningkatkan hasil belajar peserta didik kelas IX.A SMP Negeri 1 Sakra Barat. Meningkatnya hasil belajar ini dikarenakan dalam proses pembelajaran yang dilakukan dalam penelitian peserta didik berperan 
aktif dalam proses pembelajaran. Adanya peningkatan hasil belajar peserta didik dapat dijadikan sebagai indikator bahwa peserta didik sudah melakukan proses belajar.

\section{Respon Peserta Didik}

Respon peserta didik merupakan tanggapan peserta didik terhadap pembelajaran yang dilakukan. Pada penelitian ini pembelajaran dilakukan dengan model pembelajaran kooperatif tipe TGT, respon peserta didik terhadap pembelajaran dalam penelitian ini diukur dengan menggunakan angket. Angket respon peserta didik mencakup tanggapan peserta didik terhadap pembelajaran dengan menerapkan model pembelajaran kooperatif tipe TGT. Berdasarkan data dari angket, diperoleh hasil bahwa menurut sebagian besar peserta didik menyatakan bahwa penerapan model pembelajaran kooperatif tipe TGT dapat membuat peserta didik memiliki kemauan untuk mengikuti pembelajaran; memiliki kemauan untuk memanfaatkan waktu belajar dengan baik; peserta didik berani dan aktif dalam menjawab, bertanya dan menyampaikan pendapat; meningkatkan kerjasama kelompok; peserta lebih mudah memahami materi dengan pembelajaran yang dilakukan peneliti.

Berdasarkan data di atas, secara garis besar dapat disimpulkan bahwa peserta didik lebih senang jika pembelajaran dilakukan dengan melibatkan peserta didik secara aktif dalam proses pembelajaran seperti diskusi dan praktikum. Peserta didik merasa termotivasi dan lebih mudah memahami materi yang diajarkan dengan menerapkan model pembelajaran kooperatif tipe TGT.

\section{KESIMPULAN}

Berdasarkan hasil penelitian dan pembahasan yang telah dijabarkan pada bab sebelumnya, dapat disimpulkan bahwa :

1. Penerapan model pembelajaran kooperatif tipe TGT dapat meningkatkan hasil belajar peserta didik kelas IX.A di SMP Negeri 1 Sakra Barat. Hal ini terlihat pada persentase peningkatan hasil belajar pada siklus II lebih besar dari siklus I. Rata-rata skor post test siklus I sebesar 64, sedangkan rata-rata skor post-test siklus II sebesar 70. Persentase peningkatan ketuntasan belajar peserta didik siklus I sebesar $56 \%$, sedangkan persentase peningkatan ketuntasan belajar peserta didik siklus II sebesar $\mathbf{8 4 . 8 4 \%}$ 
2. Penerapan model pembelajaran kooperatif tipe TGT mendapat respon positif dari peserta didik kelas IX.A SMP Negeri 1 Sakra Barat. Penerapan model pembelajaran ini dapat membuat peserta didik lebih aktif dalam proses pembelajaran.

\section{DAFTAR PUSTAKA}

Antonim. Model-Model Pembelajaran Bagi Pendidikan Kejuruan dan Karya Tulis Ilmiah.Bahan Bimtek Lomba Karya Tulis Ilmiah Inovatif Produktif.

Angkoro, R. dan Kosasih, A. 2007.Optimalisasi Media Pembelajaran.Jakarta. PT. Grasindo.

Dimyati dan Mudjiono. 2009. Belajar dan Pembelajaran. Jakarta. P'T. Rineka Cipta.

Djamarah, Syaeful Bahri.2005.Guru dan Anak Didik dalam Interaksi Anak Didik, Rineka. Cipta.

IL Pasaribu, B Simandjuntak.1983. Proses Belajar Mengajar. Bandung: Tarsito

Nasution, S. 2006. Berbagai Pendekatan dalam Proses Belajar \& Mengajar. Jakarta : Bumi Aksara.

Sudjana, Nana. 2010. Penelitian Hasil Proses Belajar Mengajar. Bandung : PT. Remaja Rosdakarya.

Slavin, E. Robert. 2008. Cooperative Learning (Teori, Riset dan Praktik). Bandung : Nusa Media.

Sriyono. 1992. Teknik Belajar Mengajar CBSA. Jakarta: Rineka Cipta.

Susilo, H., Chotimah, H., Dwita, S.Y. 2009.Penelitian Tindakan Kelas Sebagai Sarana Pengembangan Keprofesionalan Guru dan Calon Guru. Malang, Bayumedia Publishing.

Tim. 2011. Kurikulum SMP Negeri 1 Sakra Barat.Janapria.

Winatasaputra, Udin S. dkk. 2009. Teori Belajar dan Pembelajaran.Jakarta. Universitas Terbuka. 